\title{
MESENCHYMAL STEM CELLS: A PERSPECTIVE FROM IN VITRO CULTURES TO IN VIVO MIGRATION AND NICHES
}

\author{
Andrea Augello, Tobias B. Kurth, Cosimo De Bari* \\ Regenerative Medicine Unit, Bone \& Musculoskeletal Research Programme, Division of Applied Medicine, \\ University of Aberdeen, Aberdeen, UK
}

\begin{abstract}
Mesenchymal Stromal Progenitor/Stem Cells (MSCs) are a rare population of non-hematopoietic stromal cells, present in the bone marrow and most connective tissues of the body. They are capable of differentiation into mesenchymal tissues such as bone, cartilage, adipose tissue and muscle. In the absence of specific markers, MSCs have been defined following isolation and culture expansion, by their expression of various molecules including CD90, CD105 and CD73 and absence of markers like CD34, $\mathrm{CD} 45$, and CD14. MSCs have extensive proliferative ability in culture in an uncommitted state while retaining their multilineage differentiation potential, which make them attractive candidates for biological cell-based tissue repair approaches. However, their identity in their tissues of origin is not clear and the niches in which they reside are not defined. This review addresses the current state of MSC research including the differentiation potency of culture expanded MSCs, expression of chemokines and their receptors in MSCs - both relevant issues for the advocated use of MSCs for tissue repair and their systemic delivery to the affected tissues. It also reviews current knowledge of MSC niches in their native tissues, addressing the relationship with pericytes. Finally, it provides a scientific basis for the requirement of a thorough characterisation of the endogenous MSC niches within their native tissues in vivo. The knowledge of MSC niches will instruct development of innovative therapeutic measures such as producing pharmacological substances that target endogenous MSCs and their niches in order to activate and guide intrinsic repair and to improve disease outcomes.
\end{abstract}

Keywords: Stem cells, mesenchymal stromal progenitors, niche, pericytes, regenerative medicine, migration, chemokines, differentiation, cartilage, bone.

*Address for correspondence:

Cosimo De Bari

Institute of Medical Sciences

Foresterhill, Aberdeen AB25 2ZD, U.K.

Telephone Number: +44-1224-551362

FAX Number: +44-1224-555766

E-mail: c.debari@abdn.ac.uk

\section{Mesenchymal Stromal Progenitor/Stem Cells}

After placing whole bone marrow cells in plastic culture dishes with medium supplemented with $10 \%$ foetal calf serum, Friedenstein et al. (1970) demonstrated that bone marrow contains hematopoietic non-adherent cells along with a rare population of plastic-adherent cells (approximately 1 in 10,000 nucleated cells in the bone marrow). These cells were able to form colonies derived from single cells. After a few days, these adherent cells, of heterogeneous appearance, start to proliferate and can differentiate into mature cells of mesenchymal lineages such as osteoblasts (Friedenstein et al., 1970; Friedenstein et al., 1976). The initial clones of adherent cells expanded into round-shaped colonies composed of fibroblastoid cells, thus the term of Colony Forming Unit - fibroblasts (CFU-f). Friedenstein also found that some of the colonies could differentiate into aggregates resembling small areas of bone or cartilage. Other groups then extended these initial observations, studying CFU-f proliferative abilities and phenotypic characteristics (Castro-Malaspina et al., 1980; Prockop, 1997; Caplan and Bruder, 2001), and it was established that these cells were multipotential and could differentiate into osteoblasts, chondrocytes, adipocytes, and even myoblasts. Each bone marrow donor shows a specific frequency of CFU-f, which is dependent on the age and health of the donor. The current categorization of these cells is either mesenchymal stem cells (MSCs) as proposed by Caplan (1991), because of their ability to differentiate into cells of the mesenchymal lineages, or stromal cells because they belong to the stroma that is believed to have a physical supporting role to the hematopoietic stem cell (HSC) niche (Devine and Hoffman, 2000; Wilson and Trumpp, 2006). Whether these cells should be considered true stem cells at all or as multipotent progenitors of mesenchymal lineages has been the focus of intense debate. It has therefore been proposed the term "multipotent mesenchymal stromal cells" is adopted in place of "mesenchymal stem cells" (Horwitz et al., 2005; reviewed in Bianco et al., 2008).

\section{MSCs: Definition and Tissue Sources}

The definition of MSCs relies solely on the analysis of in vitro culture-expanded cell populations. Despite years of intense investigation, the location and role of the native MSCs within their tissue of origin in vivo are not known, mainly because of the lack of specific markers allowing their unambiguous identification (Bianco et al., 2008; Jones and McGonagle, 2008; Morikawa et al., 2009). The possibility exists that the MSC phenotype and abilities 
vary between in vivo and in vitro settings due to the removal from their natural environment and the use of chemical and physical growth conditions that might alter their characteristics. MSCs are known to undergo phenotypic rearrangements during ex vivo manipulations, losing expression of some markers while also acquiring new ones (Jones et al., 2002). Due to the growing interest in using MSCs in cell-based therapy (Barry and Murphy, 2004; De Bari and Dell'Accio, 2008), the need to identify MSCs in a definitive way is not only a scientific interest but also derives from clinical and regulatory requirements (Sensebé, 2008; Sensebé et al., 2010). As noted above, no unique markers can unequivocally identify a MSC and distinguish it from other cell types. In 2006, the International Society for Cell Therapy proposed the following criteria for the minimal identification of human MSCs (Dominici et al., 2006): adherence to plastic in standard culture conditions; $\mathrm{CD}_{73}^{+}, \mathrm{CD}^{+}, \mathrm{CD} 105^{+}$, CD34, CD45-, HLA-DR-, CD14- or CD11b-, CD79a or CD19- cell phenotype as assessed by FACS analysis; in vitro differentiation into osteoblasts, adipocytes and chondroblasts (demonstrated by staining of in vitro cell culture). These criteria allow only a retrospective definition of a cell population containing MSCs but do not allow prospective purification of MSCs. In addition, these criteria are not entirely valid across and intra species. In mouse models, MSCs differ frequently not only from the human MSCs, but also between strains in marker expression and behaviour in culture (Peister et al., 2004; Sung et al., 2008), the major differences being in the expression of CD34 and CD105 (for CD105 and other markers see also Fiorina et al., 2009). These criteria are overly dependent on culture conditions for derivation and expansion of MSC populations and, therefore, are unlikely to be extrapolated to the native cells. Indeed, MSCs are expanded under conditions that maintain the typical MSC differentiation potency but do not preserve what is currently considered to be the native MSC phenotype (Jo et al., 2007; Morikawa et al., 2009).

Isolation of MSCs has been performed in several species (Friedenstein, 1970) including humans (CastroMalaspina, 1980; Haynesworth, 1992; Bruno et al., 2009; Yoo et al., 2009) and mice (Gindraux et al., 2007; Sung et al., 2008), and from many tissues other than the bone marrow, including peripheral blood (Zvaifler et al., 2000), cord blood (Erices et al., 2000), cord Wharton's jelly (Sarugaser et al., 2005), adipose tissue (Zuk et al., 2002), amniotic fluid (In't Anker et al., 2003), compact bone (Guo et al., 2006), periosteum (Nakahara et al., 1991; De Bari et al., 2001a; De Bari et al., 2006a), synovial membrane (De Bari et al., 2001b; De Bari et al., 2003) and synovial fluid (Jones et al., 2004), articular cartilage (Dowthwaite et al., 2004) and foetal tissues (Campagnoli et al., 2001; Miao et al., 2006). Cells derived from different tissues show phenotypic heterogeneity and different growth abilities, but they also show similarities, with the potential to differentiate into the classical mesenchymal lineages and the expression of common surface markers (Baksh et al., 2007). However, there is increasing evidence that marked differences exist in the biology of MSCs that are dependent on the tissue of origin, which appears to be the main source of variation in the biological properties of MSCs (De Bari et al., 2008). Within each tissue source, single-cell-derived clonal MSC populations are known to be highly heterogeneous in their proliferative and differentiation potential (De Bari et al., 2008; Phinney and Prockop, 2007). The resulting variability limits standardization of MSC-based bone repair strategies and impedes the comparison of clinical study outcomes. There is, therefore, an unmet clinical need for assays that allow quantitative estimation of the differentiation potency of MSC preparations. Such potency assays would allow development of quality controls for efficacy of MSC preparations (De Bari et al., 2006c; De Bari and Dell'Accio, 2007), a vital prerequisite for their routine use in clinical practice.

Cells with properties of MSCs have also been isolated from tissues in several pathological conditions, sometimes with distinctive features. For instance, in the rheumatoid arthritic joint, MSC-like cells appear to express bone morphogenetic protein (BMP) receptors (MarinovaMutafchieva et al., 2000). In the peripheral blood of acute burns patients, Mansilla et al. (2006) reported increase in circulating MSC-like cells compared with healthy donors, with greater numbers found among younger patients with more extensive burns. It is postulated that MSCs are mobilized into the bloodstream following acute burn signals which have not yet been elucidated. In other pathological conditions, such as obstructive apnoeas and bone sarcomas, studies provide evidence of possible mobilization of MSCs which increase in their circulating numbers compared to healthy individuals (Carreras et al., 2009; Bian et al., 2009); these reports are initial studies, often imprecise in the definition of MSC phenotype, and therefore they warrant further more accurate studies to understand the mechanisms underlying MSC mobilization in vivo, its biological significance and possible clinical impact in terms of recruitment to tissue and wound healing.

Intense investigation on MSC isolation studies the use of monoclonal antibodies in order to pre-select cells with an MSC surface phenotype; the methods vary from negative selection, where other cell types, such as hematopoietic cells, are removed (Baddoo et al., 2003), to positive selection, when MSCs are directly enriched from a pool of other cells in which they are known to be present (Jones et al., 2002; Quirici et al., 2002; Deschaseaux et al., 2003; Jones et al., 2006; Buhring et al., 2007; Gindraux et al., 2007; Battula et al., 2009). This proves very challenging in view of the lack of specific markers and the phenotypic plasticity that MSCs demonstrate in vitro (Jo et al., 2007). There are ongoing efforts to come up with marker sets that would include positive and negative selection, in order to obtain enrichment and, ideally, purification from native tissues of MSC subsets with a consistent and clinically desired potency, which is a prerequisite for development of standardized, GMPcompliant cell therapy in a clinical setting. Currently, the intense investigation of prospective MSC isolation markers has led to the identification of a variety of molecules that could prove useful in the in vivo identification and 
purification of MSC-like cells (reviewed in Jones and McGonagle, 2008); prominently among them are LNGFR (CD271), a neural marker repeatedly found to be expressed by MSCs (Jones et al., 2002; Quirici et al., 2002; Jones et al., 2006; Buhring et al., 2007; Battula et al., 2009), and CD49a (Deschaseaux et al., 2003; Jones et al., 2006), together with the markers already indicated by the International Society for Cell Therapy (Dominici et al., 2006). Recently, PDGFR $\alpha+$ Sca-1+CD45-TER119- cells have been isolated from murine BM with abilities and characteristics consistent with conventional plasticadherent MSCs (Morikawa et al., 2009). It is anticipated that the adoption of MSC purification procedures will allow a one-stop therapeutic approach, involving rapid production of uncultured MSCs for immediate administration to patients.

\section{Differentiation Potency of Culture-Expanded MSCs}

\section{General concepts}

Among the criteria used to define MSCs is the ability to differentiate in vitro into the three mesenchymal lineages, i.e. bone, cartilage and fat. The classical osteogenic differentiation of human MSCs (Jaiswal et al., 1997; Pittenger et al., 1999) requires incubation of cell monolayers with ascorbic acid, $\beta$-glycerophosphate, and dexamethasone (added to medium containing FBS), resulting in increase in alkaline phosphatase and calcium deposition. The chondrogenic differentiation requires a high cell-density pellet or micromass culture in conjunction with the use of transforming growth factor- $\beta$ in a chemically defined serum-free medium; the histological analysis reveals production of cartilage-specific highly sulphated proteoglycans and type II collagen. The adipogenic differentiation requires treatment with dexamethasone, insulin, isobutyl methyl xanthine, and indomethacin (added to medium containing FBS), and is revealed by the appearance of lipid vacuoles detected with oil red O staining. In Pittenger's report, some of the clonalderived populations were able to differentiate into all three lineages, but other clonal populations were lacking differentiation into at least one lineage. Notably, all clonal populations were able to undergo osteogenesis (Pittenger et al., 1999). In following studies, many of the human MSC populations were reported as readily differentiating into the three lineages, and they were undergoing a sequential loss of lineage potential with the osteogenic precursors as residual cells (Muraglia et al., 2000), indicating the possible existence of a hierarchical model of differentiation.

There is increasing evidence to indicate that MSC populations are heterogeneous with coexisting subsets having varying potency, and this applies to bone marrow MSCs as well as those from other tissues. In this regard, we recently reported that human synovium-derived clonal MSCs were all capable of osteogenic and chondrogenic differentiation though with varying potency, where only $30 \%$ of the clonal populations tested were able to differentiate into adipocytes (Karystinou et al., 2009).

Under appropriate conditions, MSCs have been shown to differentiate also into other mesenchymal lineages such as skeletal myocytes and tenocytes (Wakitani et al., 1995; De Bari et al., 2003; Hoffmann et al., 2006). Notably, there are reports indicating the capacity of MSCs to differentiate into non-mesenchymal lineages such as neurons (Woodbury et al., 2000). The clinical relevance of the presumptive non-mesenchymal potency of MSCs is however questioned since MSC-derived neuron-like cells were unable to generate action potentials and therefore function as neurons (Hofstetter et al., 2002).

\section{MSC-derived cartilage and bone}

Particular attention has been devoted to the chondrogenic and osteogenic abilities of MSCs. This is because it is hypothesized that MSCs with their natural mesenchymal potency would primarily be used for the biological repair of articular cartilage and bone. The osteogenic potential of whole bone marrow population first (Friedenstein et al., 1966; Luria et al., 1987) and of culture-expanded MSCs later (Friedenstein, 1976; Ashton et al., 1985) has been studied extensively in in vitro and in vivo experiments. The first in vivo experiments were performed using diffusion chambers loaded with whole bone marrow (Friedenstein et al., 1966) or with culture-expanded cells (Ashton et al., 1980). Later, the adoption of bioscaffolds, such as hydroxyapatite (HA) implanted in immunocompromised mice has proved useful to help understanding the mechanisms of MSCs differentiation in vivo (Ohgushi and Okumura, 1990). In studies in nude mice, Muraglia et al. (1998) were able to develop donorderived bone by subcutaneous implantation of HA scaffolds seeded with human MSCs. Later, it became possible to repair large bone defects in vivo by using autologous MSCs, in loaded conditions, both in large animals (Kon et al., 2000) as well as in humans in a proofof-concept study (Quarto et al., 2001). In another set of in vivo human studies, Horwitz et al. (1999) reported that bone marrow transplantation in three children affected by osteogenesis imperfecta (OI) resulted in enhancement of bone structure with differentiation of donor MSCs into functional osteoblasts. In a subsequent study (Horwitz et al., 2002), allogeneic bone marrow-derived MSCs were safely administered to children with severe OI, and were shown to engraft in genetically defective bone and differentiate into osteoblasts.

Aslan et al. (2006) purified CD105+ cells from human bone marrow that were able to differentiate in vitro and in vivo toward the osteogenic lineage. Such an approach highlights the clinically relevant possibility that functionspecific cell types could be purified and directly used for tissue engineering/repair purposes, without the need for time-consuming and costly cell culture expansions. Although it cannot be ruled out that a relatively low number of "true" stem cells may be sufficient to provide repair, purification strategies appear unlikely to yield adequate quantities of MSCs at least for repair of large defects, especially in view of their known low frequency.

Another unresolved issue pertains to the MSC type to use in clinical practice, given the plethora of tissue sources. For instance, human periosteum is also known to contain cells that upon enzymatic release and culture expansion display MSC phenotype and capacity at the single cell 
level to differentiate into multiple skeletal lineages including bone in vitro and in vivo (De Bari et al., 2006a). Notably, in a proof-of-concept study we quantified the bone-forming potency of matched human MSCs from synovium and periosteum and analyzed the sources of variability in osteogenic outcome. We identified the tissue of origin of MSCs as the main source of variability, since MSCs from periosteum had significantly greater osteogenic potency than MSCs from synovium. A second source of variability was related to the individual donor, within each tissue. We measured the basal expression levels of osteoblast-lineage genes in clonal MSCs prior to osteogenic treatment, identified biomarkers that correlated with osteogenic outcome and developed a mathematical model that predicts bone-forming potency of clonal MSC preparations, independent of donor and tissue source (De Bari et al., 2008). The development of a biomarker-based model that predicts the osteogenic potency of human MSC preparations is of considerable clinical relevance. A similar approach is likely to increase consistency of therapies that employ MSCs for bone repair. It may also facilitate the selection of individuals that qualify for MSC-based bone repair and help identify the best source and preparation protocol of human MSCs. It remains to be investigated whether the same formula can be applied successfully to MSC-based orthotopic bone repair in a preclinical model, where it is easy to think that in addition to the properties intrinsic to the cell preparation, other factors such as inflammation and biomechanics will influence bone formation.

While bone formation is relatively straightforward when MSCs are loaded onto matrices and then implanted subcutaneously in mice, the formation of stable cartilage appears to be a very challenging task with MSCs. The chondrogenic potential of MSCs is well known in vitro in pellet cultures but the key question as to whether this is stable cartilage or a transient cartilage template destined to be replaced with bone in a process of endochondral ossification remains to be addressed. Using a nude mouse assay of ectopic cartilage formation validated with intramuscular injection of adult human articular chondrocytes (Dell'Accio et al., 2001), we demonstrated that the in vitro chondrogenic potential of synovial membrane-derived MSCs is not sufficient to predict the in vivo outcome at least in this nude mouse model, since the synovial MSCs induced in vitro into a chondrocytelike phenotype failed to form stable cartilage when implanted in vivo (De Bari et al., 2004). Of note, Pelttari and colleagues reported that bone marrow MSC-derived cartilage pellets transplanted into ectopic sites in SCID mice underwent endochondral ossification, via premature induction of chondrocyte-hypertrophy-related molecules such as type X collagen (Pelttari et al., 2006). These studies, however, do not rule out the possibility that, as opposed to an ectopic site, the joint environment of a cartilage defect may instead be sufficient either to induce a stable cartilage phenotype or stabilize the chondrocyte-like phenotype of in vitro pre-committed MSC populations. Uplift of the bone front at the expense of the overlying articular cartilage has been observed in osteochondral repair by bone marrow cells (Qiu et al., 2003). This phenomenon has not been reported in patients treated with autologous chondrocyte transplantation and therefore one may argue that the phenotypic memory of articular chondrocytes could possibly limit the advancement of the bone front, thus preserving the normal thickness of the repaired cartilage tissue (De Bari et al., 2006b).

\section{Expression of Chemokines and Their Receptors in MSCs}

The knowledge of native MSC biology and interactions with their nearby microenvironment, i.e. the stem cell niche, in healthy versus damaged or diseased tissues will provide guidance on future clinical applications employing MSCs. A challenge that the biomedical community will face in regenerative medicine is the re-establishment of a functional niche similar to the physiological one when regenerating or healing damaged tissues. The restoration of a functional niche will indeed be essential to safeguard durable repair and ensure continual replacement of mature cells lost to physiological turnover or subsequent stress or damage.

Stem cell niches have been described so far for a number of tissue types such as the hair follicle, intestine and the bone marrow (Fuchs et al., 2004; De Bari et al., 2006c). The niche of hematopoietic stem cells (HSCs) in bone marrow might serve as a good example for the complexity of the niche functional concept. It is commonly regarded that the HSC niche consists of at least two distinct niches, the endosteal niche where hematopoietic stem cells are in close contact with osteoblasts residing at the bone surface of the trabeculae, and the perivascular niche where the HSCs are found close to the sinusoids in the bone marrow (Mitsiadis et al., 2007). In the endosteal niche signalling events between osteoblasts and HSCs play a crucial role in maintenance and activation of stem cells (reviewed in Kiel and Morrison, 2009). Pathways like Notch and Wnt signalling are known to be involved (Calvi et al., 2003; Reya et al., 2003; Duncan et al., 2007), and the SDF-1/CXCR4 system is part of the complex signalling network.

Chemokines are small $(8-10 \mathrm{kDa})$ proteins able to chemically attract lymphocytes, neutrophils and other immune cell types to the sites of inflammation. Several families of chemokines and their receptors exist, each with different characteristics and abilities. The chemokine SDF1 is expressed on osteoblasts and endothelial cells and the interaction with CXCR4 is thought to regulate trafficking of HSCs in the bone marrow (Semerad et al., 2005). In the perivascular niche, sinusoidal reticular cells express high levels of SDF-1 and were found to be in close contact with HSCs (Sugiyama et al., 2006). Interestingly, these SDF-1 expressing reticular cells were also located at the endosteal niche. The fact that HSCs express the receptor CXCR4 (Peled et al., 1999) suggests that the SDF-1/ CXCR4 system would be crucial for the modulation of activation or quiescence of the HSC niche in bone marrow.

Similarly to HSCs, chemokines and their receptors might be of importance for MSCs in their niche. MSCs have been reported to express varying degrees of 
chemokines and chemokine receptors, with differences being likely due to the isolation techniques and in vitro culture conditions (Honczarenko et al., 2006; Djouad et al., 2007). Sordi et al. (2005) reported that chemokine receptors (namely CXCR4, CX3CR1, CXCR6, CCR1 and CCR7), expressed by a minority ( $2 \%-2.5 \%)$ of the MSCs, were linked to the in vivo migratory abilities of MSCs toward murine pancreatic islets.

Few data are available regarding the existence of a MSC niche in vivo (reviewed in da Silva Meirelles et al., 2008), and they suggest a perivascular location of the MSCs (reviewed in Kuhn and Tuan, 2010), although this notion is challenged by the retrieval of MSC-like cells in avascular tissues such as articular cartilage (Barbero et al., 2003; Dell'Accio et al., 2003; Dowthwaite et al., 2004). Tissue-specific MSC niches are likely to exist, since tissuespecific distinct MSC phenotypes and functions have been reported (Hennig et al., 2007; Roubelakis et al., 2007; Meijer et al., 2008; Zhu et al., 2008; Hwang et al., 2009; Ivanova-Todorova et al., 2009), and also embryologically MSC could derive from non-mesodermal progenitors, such as neuro-epithelial cells (Takashima et al., 2007). The study of the migratory abilities of MSCs in vivo will elucidate the requirements for homing and engraftment of such cells and therefore underpin common features of a generic MSC niche.

Systemically infused MSCs have been retrieved in multiple organs such as lung, liver, kidney, and spleen (Barbash et al., 2003; Devine et al., 2003; Kraitchman et al., 2005), but also in specific targets, such as sites of inflammation, injury, tumors and tissues already known to contain MSCs such as the bone marrow (Devine et al., 2001; Belema-Bedada et al., 2008; Sackstein et al., 2008). Cultured MSCs used as a therapeutic tool in vivo by means of systemic infusion were retrieved in the site of action in some experimental models (Zappia et al., 2005; Sasaki et al., 2008), but not in other models (Augello et al., 2007). Freshly isolated, uncultured MSCs have been reported to migrate to bone marrow and spleen after systemic transplantation in experimental animal models (Rombouts and Ploemacher, 2003; Mahmud et al., 2004; Morikawa et al., 2009). In contrast, culture-expanded MSCs appear unable to migrate and home to the bone marrow (Rombouts and Ploemacher, 2003; Karp and Leng Teo, 2009; Morikawa et al., 2009). Recent reports show that following clinical bone marrow transplantation human MSCs are of host origin (Bartsch et al., 2009). A parabiosis study from Maloney et al. (1985) demonstrated that in mice in parabiotic equilibrium where one partner had been Xirradiated, repopulation of the CFU-F compartments of the bone marrow in the irradiated mouse resulted from recovery of the local CFU-F and not from migration of CFU-Fs from the parabiotic, non-irradiated partner. The apparent discrepancy in findings on MSC homing and engraftment may be explained by the differences in model systems, the adoption of freshly isolated MSCs versus culture-expanded MSCs and also the different culture conditions, likely to affect MSC phenotype and hence their migratory patterns. Nonetheless, it is believed that MSCs, when infused intravenously, have potential to migrate to sites of injury, such as to adult brain (Ji et al., 2004), embryonic brain (Munoz-Elias et al., 2004), infarcted myocardium (Barbash et al., 2003; Schenk et al., 2007), injured skeletal muscle (De Bari et al., 2003) and kidney (Morigi et al., 2004). MSCs have repair and immunomodulatory abilities also in mouse lungs, reducing systemic response to endotoxin when infused intravenously, but disappear from the site of injury after a short time lapse (Xu et al., 2007).

Several reports indicate that the SDF-1 (CXCL12)/ CXCR4 axis is present and functional in MSC populations (Wynn et al., 2004; Dar et al., 2005). Recently, it has been demonstrated that this pathway is crucial in the migration of MSCs to injury sites such as bone fractures, with absence of MSC recruitment if SDF-1 signalling was impaired (Kitaori et al., 2009). Ma et al. (2005) investigated the time course of myocardial SDF-1 expression and effects of intravenously administered bone marrow-derived MSCs in rats with experimental myocardial infarction (Ma et al., 2005). Myocardial SDF-1 expression was increased only in the early phase post-infarct, and as a result only MSCs intravenously infused in temporal vicinity to the early phase of MI were recruited to injured myocardium, enhancing angiogenesis and improving cardiac function, while MSCs injected when the cardiac SDF-1 expression had already fallen did not home to the heart or have a positive effect on the MI outcome. These findings raise the need for identification of a temporal therapeutic window for intervention with MSCs

There is evidence that MSCs can respond to chemotactic signalling molecules acting on pathways other than the SDF-1/CXCR4 axis. One of those is the Monocyte Chemotactic Protein-3 (MCP-3). Schenk et al. (2007) showed that when systemically infused, MSCs migrated transiently toward the infarcted myocardium in response to MCP-3 signalling. The Authors then induced migration of MSCs to the infracted area by previous implantation of MCP-3-over-expressing cardiac fibroblasts in the infarct border zone. Structural and functional improvements were reported, mainly due to remodelling of the cardiac collagen matrix, in the absence of angiogenesis and without cardiomyocyte regeneration.

Migrating MSCs may therefore represent a source of multipotent cells that could be available for the repair of damaged tissues and organs. However, the mechanisms that underlie homing of implanted cells are still unclear and may be merely a stochastic event or explainable with the vasodilatation and increased blood supply (and cells) to the injured areas of the body. It is also postulated that MSCs could have the ability to interact with immune cells during inflammation; these interactions could have an impact on the way MSCs contribute to the repair process in recipients in vivo (Ohtaki et al., 2008; Constantin et al., 2009). Understanding the underlying mechanisms of action as part of the pharmacology of cell therapy is thus of paramount importance in view of the increasing number of clinical trials with MSCs, as this is anticipated to allow forecasting the outcome of MSC-based treatments. 


\section{MSCs and Pericytes: a Catch-22?}

A major unresolved question relates to the identity of MSCs within their native tissues. There is growing evidence that pericytes may be the native cells of the ex vivo MSCs. Pericytes, also known as mural cells or Rouget cells, are described as branched cells located on the abluminal side of small blood vessels (arterioles, capillaries and venules) and are in close connection with the vessels' endothelial cells. The functions of pericytes include vessel stabilization, synthesis of matrix proteins, macrophagelike properties, activity in immunologic defence and, possibly, mesenchymal potentiality (reviewed in DiazFlores et al., 2009). Of special interest in this regard is the perivascular MSC niche hypothesis. A stem cell niche is defined as the microenvironment where the adult stem cell resides and includes surrounding cells and extracellular matrix, both thought to provide signals that keep the stem cells quiescent or instead modulate their activation. In the case of activation, stem cells undergo either symmetric division or asymmetric division, i.e. they give rise to daughter cells that are both stem cells or they produce progeny one of which is a stem cell while the other daughter cell is already committed to its differentiation fate. The proximity to vessels would allow pericytes quickly to enter the bloodstream to replace cells lost due to physiological turnover or repair of local lesions (da Silva Meirelles et al., 2008). Brighton et al. (1992) demonstrated that pericytes exhibit in vitro a phenotype similar to that of bone marrow-derived bone cells (MSCs). Diaz-Flores and colleagues provided evidence by Monastral Blue staining that pericytes could be involved in generating cartilage and bone (Diaz-Flores et al., 1991; Díaz-Flores et al., 1992). Furthermore, pericytes from various adult and foetal tissues have been shown to express MSC markers such as CD44, CD73, CD90 and CD105. Freshly isolated pericytes from the placenta were shown to be myogenic when injected into SCID-mdx-mice (Crisan et al., 2008). However, despite growing circumstantial evidence that pericytes might be the in vivo native cells of the ex vivo MSCs, there has been no direct evidence up to now that pericytes have key features of stem cells including proliferation and differentiation into mature cell phenotypes in vivo following injury by prospective cell lineage tracking experiments, a requirement that should apply as well to other putative MSC populations. In their recent study, Crisan and colleagues indeed concluded that pericytes might not be the only source of MSCs (Crisan et al., 2008). The question therefore remains open as to whether the MSC is a unique cell type, distinct from the pericyte, with the specific function to replace mature mesenchymal cells lost to physiological turnover, injury or disease, or if there are multiple subsets of MSCs or progenitor cells, which might be functionally distinct. Celllineage tracking experiments, now increasingly feasible with modern technologies and detection systems, will shed light on these unresolved issues related to the in vivo nature of the native MSCs in the natural environment of their intact tissues.

\section{Conclusion}

The advancement of therapeutic approaches using MSCs is currently somewhat constrained by the lack of data about the in vivo properties of the native MSCs within their tissues and niches. The proliferation and differentiation data, as well as the marker definition, are all related to the in vitro culture systems, which are likely to alter the natural characteristics that these cells have in vivo. Another problem arises from the fact that frequently the data obtained through in vitro manipulation are not reproducible when translating to in vivo applications even when using the same batch of cells. Bianco and co-workers found that even parallel cultures of cells extracted from the same batch could not demonstrate true multipotency (Bianco et al., 2008). So far, in most of the clinical skeletal tissue engineering applications in which MSCs have been used the investigators applied large numbers of cells in order to physically fill the defects, and therefore a culture expansion stage was unavoidable. However, no conclusive data have been produced showing that a higher number of cells is more adequate and efficacious to repair a large defect than a smaller number of purified and potent stem cells. Moreover, when applying the concepts of tissue repair to some clinical settings such as small cartilage lesions, many investigators have started to indicate that one possible way to use MSCs therapeutically is through pharmacological targeting of endogenous MSCs and related niches, without the need to remove the cells from their environment, culture expand them and then implant them back to patients, thus avoiding culture-related modifications such as possible malignant transformation of the cells and risks of adverse immune reactions e.g. to components of the FBS used in culture (reviewed in Tonti and Mannello, 2008).

The ex vivo expansion of mixed cell populations is likely to lead to unsatisfactory tissue repair, e.g. because of possible contamination of undesired cell types that could even interfere with the repair process (Fig. 1A). This is likely to make cell therapy inconsistent and unreliable. There is therefore a clinical and regulatory requirement to devise technologies for prospective purification of cells with the desired potency in order to standardise cell-based therapy, and ensure consistent and reproducible structural and clinical outcome. Such purification could be either from fresh tissue sources or from culture-expanded mixed cell populations (Fig. 1B and C). In some clinical applications, it may be possible to purify the cells of interest with known and predictable potency directly from the tissue sources (e.g., bone marrow) and implant the purified cells intra-operatively using a one-step procedure (Fig. 1D). The purification of the desired cell type could be coupled with the concurrent purification of other cell types, such as endothelial cells, that could prove to be beneficial in assuring a successful outcome of selected MSC-based cellular therapies (Lasala et al., 2010). A valuable option will also be the activation of intrinsic repair or regeneration by targeting endogenous MSCs with bioactive molecules (Fig. 1E). Understanding the in vivo MSC niches and their molecular regulation in health and disease is therefore of the utmost importance for the development of novel 
A

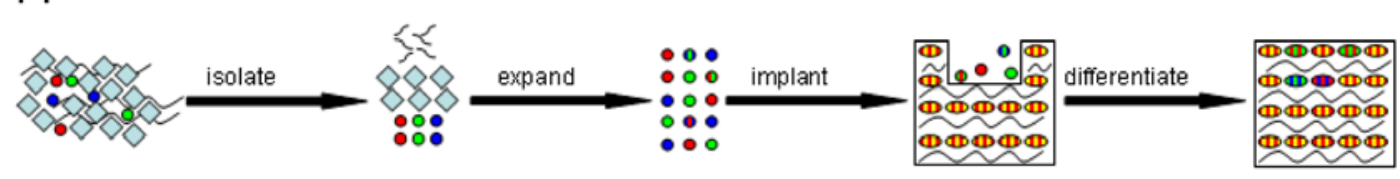

B

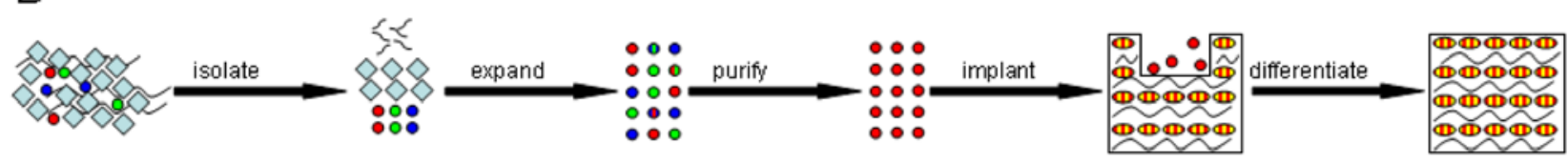

C

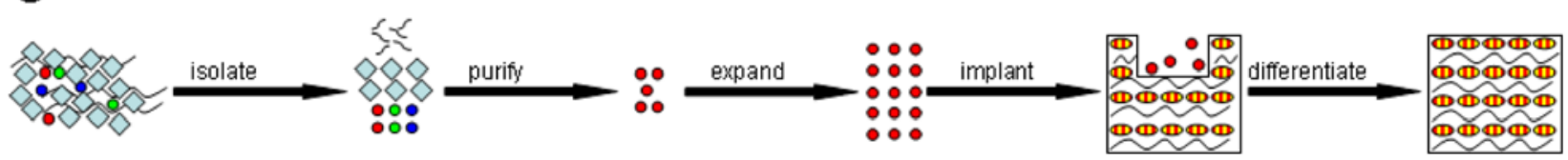

D

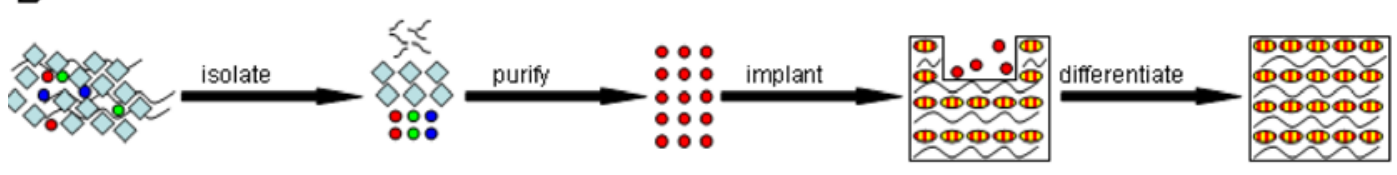

$E$

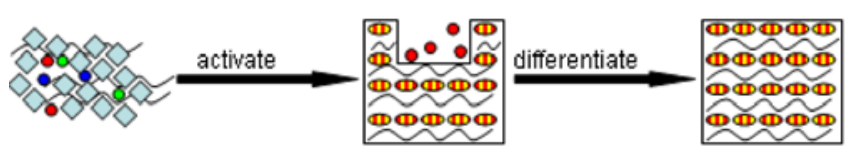

$\diamond:$ non-MSC cell

$\sim$ : Extracellular matrix

- $\bullet$ : MSCs with different phenotypes

- - : MSCs with changing phenotypes

II : Mature cell with carrect phenotype

(1) : Mature cell with incarrect phenotype

Fig. 1: Tissue repair strategies using MSCs. (A) MSCs of potentially different phenotypes are isolated from their native tissue and culture expanded. Due to culture conditions phenotypes might change and the repair of the defect could fail as a consequence of incorrect phenotypes of mature cells filling the defect. (B) MSCs are expanded in vitro after isolation. Enrichment based on marker combinations specific for a defined MSC phenotype would lead to differentiation into the required mature cell type. (C) MSCs are purified and culture expanded before implantation in the defect. (D) MSCs are purified after tissue release by defined selection using combinations of MSC markers. Repair of tissue defects will be of a consistent phenotype of mature cells. (E) MSCs of a defined phenotype suitable for tissue defect repair will be stimulated in vivo to migrate into the defect and then differentiate into the desired mature cell type.

pharmacological approaches to tissue repair by targeting endogenous stem cells and niches and their regulatory reparative signalling networks. The scientific community needs to devote efforts towards an in-depth understanding of the networking abilities of MSCs in vivo, in order to unravel the physiological ways by which these cells exit from the quiescent state and become activated to cope with paraphysiological or pathological conditions. There is also a need to investigate the migratory abilities of MSCs, likely to be a function of the adhesion molecules that MSCs express on their surface. With these approaches, we anticipate that one day we will be able to directly influence and guide, using tissue- and cell-specific pharmacological targets, the in vivo mechanisms that activate and direct native MSCs towards the sites of inflammation and injury in order to trigger and enhance tissue regeneration by means of directed in vivo tissue engineering.

\section{Acknowledgements}

The authors would like to acknowledge Dr. Gordon MacDonald for the critical revision of our manuscript. Supported by MRC grant G108/620. Professor De Bari is a Fellow of the Medical Research Council, UK.

\section{References}

Ashton BA, Allen TD, Howlett CR, Eaglesom CC, Hattori A, Owen M (1980) Formation of bone and cartilage by marrow stromal cells in diffusion chambers in vivo. Clin Orthop 151: 294-307.

Ashton BA, Abdullah F, Cave J, Williamson M, Sykes BC, Couch M, Poser JW (1985) Characterization of cells with high alkaline phosphatase activity derived from 
human bone and marrow: Preliminary assessment of their osteogenicity. Bone 6: 313-319.

Aslan H, Zilberman Y, Kandel L, Liebergall M, Oskouian RJ, Gazit D, Gazit Z (2006) Osteogenic differentiation of noncultured immunoisolated bone marrow-derived CD105+ cells. Stem Cells 24: 1728-37

Augello A, Tasso R, Negrini SM, Cancedda R, Pennesi G (2007) Cell therapy using allogeneic bone marrow mesenchymal stem cells prevents tissue damage in Collagen-Induced Arthritis. Arthritis Rheum 56: 11751186.

Baddoo M, Hill K, Wilkinson R, Gaupp D, Hughes C, Kopen GC, Phinney DG (2003) Characterization of mesenchymal stem cells isolated from murine bone marrow by negative selection. J Cell Biochem 89: 1235-1249.

Baksh D, Yao R, Tuan RS (2007) Comparison of proliferative and multilineage differentiation potential of human mesenchymal stem cells derived from umbilical cord and bone marrow. Stem Cells 25: 1384-1392.

Barbash IM, Chouraqui P, Baron J, Feinberg MS, Etzion S, Tessone A, Miller L, Guetta E, Zipori D, Kedes LH, Kloner RA, Leor J (2003) Systemic delivery of bone marrow-derived mesenchymal stem cells to the infarcted myocardium: feasibility, cell migration, and body distribution. Circulation 108: 863-868.

Barbero A, Ploegert S, Heberer M, Martin I (2003) Plasticity of clonal populations of dedifferentiated adult human articular chondrocytes. Arthritis Rheum 48: 1315 1325 .

Barry FP, Murphy JM (2004) Mesenchymal stem cells: clinical applications and biological characterization. Int $\mathrm{J}$ Biochem Cell Biol 36: 568-584.

Bartsch K, Al-Ali H, Reinhardt A, Franke C, Hudecek M, Kamprad M, Tschiedel S, Cross M, Niederwieser D, Gentilini C (2009) Mesenchymal stem cells remain hostderived independent of the source of the stem-cell graft and conditioning regimen used. Transplantation 87: 217 221.

Battula VL, Treml S, Bareiss PM, Gieseke F, Roelofs H, de Zwart P, Müller I, Schewe B, Skutella T, Fibbe WE, Kanz L, Bühring HJ (2009) Isolation of functionally distinct mesenchymal stem cell subsets using antibodies against CD56, CD271, and mesenchymal stem cell antigen1. Haematologica 94: 173-184.

Belema-Bedada F, Uchida S, Martire A, Kostin S, Braun T (2008) Efficient homing of multipotent adult MSCs depends on FROUNT-mediated clustering of CCR2. Cell Stem Cell 2: 566-575.

Bian ZY, Li G, Gan YK, Hao YQ, Xu WT, Tang TT (2009) Increased number of mesenchymal stem cell-like cells in peripheral blood of patients with bone sarcomas. Arch Med Res 40: 163-168.

Bianco P, Robey PG, Simmons PJ (2008) Mesenchymal stem cells: Revisiting history, concepts, and assays. Cell Stem Cell 2: 313-319.

Brighton CT, Lorich DG, Kupcha R, Reilly TM, Jones AR, Woodbury RA $2^{\text {nd }}(1992)$ The pericyte as a possible osteoblast progenitor cell. Clin Orthop Relat Res 275: 287 299.

Bruno S, Bussolati B, Grange C, Collino F, Verdun di Cantogno L, Herrera MB, Biancone L, Tetta C, Segoloni
G, Camussi G (2009) Isolation and characterization of resident mesenchymal stem cells in human glomeruli. Stem Cells Dev 18: 867-880.

Bühring HJ, Battula VL, Treml S, Schewe B, Kanz L, Vogel W (2007) Novel markers for the prospective isolation of human MSC Ann NY Acad Sci 1106: 262 271.

Calvi LM, Adams GB, Weibrecht KW, Weber JM, Olson DP, Knight MC, Martin RP, Schipani E, Divieti P, Bringhurst FR, Milner LA, Kronenberg HM, Scadden DT (2003) Osteoblastic cells regulate the hematopoietic stem cell niche. Nature 425: 841-846.

Campagnoli C, Roberts IA, Kumar S, Bennett PR, Bellantuono I, Fisk NM (2001) Identification of mesenchymal stem/progenitor cells in human firsttrimester fetal blood, liver, and bone marrow. Blood 98: 2396-2402.

Caplan AI (1991) Mesenchymal stem cells. J Orthop Res 9: 641-650.

Caplan AI, Bruder SP (2001) Mesenchymal stem cells: building blocks for molecular medicine in the $21^{\text {st }}$ century. Trends Mol Med 7: 259-264.

Carreras A, Almendros A, Acerbi I, Montserrat Daniel Navajas D, Farré R (2009) Obstructive apneas induce early release of mesenchymal stem cells into circulating blood. Sleep 32: 117-119.

Castro-Malaspina H, Gay RE, Resnick G, Kapoor N, Meyers P, Chiarieri D, Mckenzie S, Broxmeyer HE, Moore MAS (1980) Characterization of human bone marrow fibroblast colony-forming cells (CFU-F) and their progeny. Blood. 56: 289-301.

Constantin G, Marconi S, Rossi B, Angiari S, Calderan L, Anghileri E, Gini B, Bach SD, Martinello M, Bifari F, Galiè M, Turano E, Budui S, Sbarbati A, Krampera M, Bonetti B (2009) Adipose-derived mesenchymal stem cells ameliorate chronic experimental autoimmune encephalomyelitis. Stem Cells 27: 2624-2635.

Crisan M, Yap S, Casteilla L, Chen CW, Corselli M, Park TS, Andriolo G, Sun B, Zheng B, Zhang L, Norotte C, Teng PN, Traas J, Schugar R, Deasy BM, Badylak S, Buhring HJ, Giacobino JP, Lazzari L, Huard J, Péault B (2008) A perivascular origin for mesenchymal stem cells in multiple human organs. Cell Stem Cell 3: 301-313.

Dar A, Goichberg P, Shinder V, Kalinkovich A, Kollet O, Netzer N, Margalit R, Zsak M, Nagler A, Hardan I, Resnick I, Rot A, Lapidot T (2005) Chemokine receptor CXCR4-dependent internalization and resecretion of functional chemokine SDF-1 by bone marrow endothelial and stromal cells. Nat Immunol 6: 1038-1046.

da Silva Meirelles L, Caplan AI, Nardi NB (2008) In search of the in vivo identity of mesenchymal stem cells. Stem Cells 26: 2287-2299.

De Bari C, Dell'Accio F (2007) Mesenchymal stem cells in rheumatology: a regenerative approach to joint repair. Clin Sci (Lond). 113: 339-348.

De Bari C, Dell'Accio F (2008) Cell therapy: A challenge in modern medicine. Biomed Mater Eng 18: S11-S17.

De Bari C, Dell'Accio F, Luyten FP (2001a) Human periosteum-derived cells maintain phenotypic stability and 
chondrogenic potential throughout expansion regardless of donor age. Arthritis Rheum 44: 85-95.

De Bari C, Dell'Accio F, Tylzanowski P, Luyten FP (2001b) Multipotent mesenchymal stem cells from adult human synovial membrane. Arthritis Rheum 44: 19281942.

De Bari C, Dell'Accio F, Vandenabeele F, Vermeesch JR, Raymackers JM, Luyten FP (2003) Skeletal muscle repair by adult human mesenchymal stem cells from synovial membrane. J Cell Biol 160: 909-918.

De Bari C, Dell'Accio F, Luyten FP (2004) Failure of in vitro-differentiated mesenchymal stem cells from the synovial membrane to form ectopic stable cartilage in vivo. Arthritis Rheum 50: 142-150.

De Bari C, Dell'Accio F, Vanlauwe J, Eyckmans J, Khan IM, Archer CW, Jones EA, McGonagle D, Mitsiadis TA, Pitzalis C, Luyten FP (2006a) Mesenchymal multipotency of adult human periosteal cells demonstrated by single-cell lineage analysis. Arthritis Rheum 54: 1209 1221.

De Bari C, Pitzalis C, Dell'Accio F (2006b) Reparative medicine: from tissue engineering to joint surface regeneration. Regen Med 1: 59-69.

De Bari C, Pringle S, Pitzalis C, Dell'Accio F (2006c) The stem cell niche: a new target in medicine. Curr Opin Orthopaed. 17: 398-404.

De Bari C, Dell'Accio F, Karystinou A, Guillot PV, Fisk NM, Jones EA, McGonagle D, Khan IM, Archer CW, Mitsiadis TA, Donaldson AN, Luyten FP, Pitzalis C (2008) A biomarker-based mathematical model to predict boneforming potency of human synovial and periosteal mesenchymal stem cells. Arthritis Rheum 58: 240-250.

Dell'Accio F, De Bari C, Luyten FP (2001) Molecular markers predictive of the capacity of expanded human articular chondrocytes to form stable cartilage in vivo. Arthritis Rheum 44: 1608-1619.

Dell'Accio F, De Bari C, Luyten FP (2003) Microenvironment and phenotypic stability specify tissue formation by human articular cartilage-derived cells in vivo. Exp Cell Res 287: 16-27.

Deschaseaux F, Gindraux F, Saadi R, Obert L, Chalmers D, Herve P (2003) Direct selection of human bone marrow mesenchymal stem cells using an anti-CD49a antibody reveals their CD45med,low phenotype. Brit J Haematol 122: 506-517.

Devine SM, Hoffman R (2000) Role of mesenchymal stem cells in hematopoietic stem cell transplantation. Curr Opin Hematol 7: 358-363.

Devine SM, Bartholomew A, Mahmud N, Nelson M, Patil S, Hardy W, Cord S, Terry H, Chung T, Stock W, Sher D, Weissman S, Ferrer K, Mosca J, Deans R, Moseley A, Hoffman R (2001) Mesenchymal stem cells are capable of homing to the bone marrow of non-human primates following systemic infusion. Exp. Hematol 29: 244-255.

Devine SM, Cobbs C, Jennings M, Bartholomew A, Hoffman R (2003) Mesenchymal stem cells distribute to a wide range of tissues following systemic infusion into nonhuman primates. Blood 101: 2999-3001.

Diaz-Flores L, Gutierrez R, Gonzalez P, Varela H (1991) Inducible perivascular cells contribute to the neochondrogenesis in grafted perichondrium. Anat Rec 229: $1-8$.

Díaz-Flores L, Gutierrez R, Lopez-Alonso A, Gonzalez R, Varela H (1992) Pericytes as a supplementary source of osteoblasts in periosteal osteogenesis. Clin Orthop Relat Res 275: 280-286.

Díaz-Flores L, Gutiérrez R, Madrid JF, Varela H, Valladares F, Acosta E, Martín-Vasallo P, Díaz-Flores L Jr (2009) Pericytes. Morphofunction, interactions and pathology in a quiescent and activated mesenchymal cell niche. Histol Histopathol. 24: 909-969.

Djouad F, Delorme B, Maurice M, Bony C, Apparailly F, Louis-Plence P, Canovas F, Charbord P, Noël D, Jorgensen C (2007) Microenvironmental changes during differentiation of mesenchymal stem cells towards chondrocytes. Arthritis Res Ther 9: R33.

Dominici M, Le Blanc K, Mueller I, Slaper-Cortenbach I, Marini FC, Krause DS, Deans RJ, Keating A, Prockop DJ, Horwitz EM (2006) Minimal criteria for defining multipotent mesenchymal stromal cells. The International Society for Cellular Therapy position statement. Cytotherapy 8: 315-317.

Dowthwaite GP, Bishop JC, Redman SN, Khan IM, Rooney P, Evans DJ, Haughton L, Bayram Z, Boyer S, Thomson B, Wolfe MS, Archer CW (2004) The surface of articular cartilage contains a progenitor cell population. J Cell Sci 117: 889-897.

Duncan AW, Rattis FM, Dimascio LN, Congdon KL, Pazianos G, Zhao C, Yoon K, Cook JM, Willert K, Gaiano N, Reya T (2007) Integration of Notch and Wnt signalling in hematopoietic stem cell maintenance. Nat Immunol 6: 314-322.

Erices A, Conget P, Minguell JJ (2000) Mesenchymal progenitor cells in human umbilical cord blood. Br J Hematol 109: 235-242.

Fiorina P, Jurewicz M, Augello A, Vergani A, Dada S, La Rosa S, Selig M, Godwin J, Law K, Claudia Placidi C, Smith RN, Capella C, Rodig S, Adra CN, Atkinson M, Sayegh MH, Abdi R (2009) Immunomodulatory function of bone marrow-derived mesenchymal stem cells in experimental autoimmune type 1 diabetes1. J Immunol 183: 993-1004.

Friedenstein AJ (1976) Precursor cells of mechanocytes. Int Rev Cytol 47: 327-359.

Friedenstein AJ, Piatetzky-Shapiro I, Petrakova KV (1966) Osteogenesis in transplants of bone marrow cells. J Embryol Exp Morph 16: 381-390.

Friedenstein AJ, Chailakhjan RK, Lalykina KS (1970) The development of fibroblast colonies in monolayer cultures of guinea-pig bone marrow and spleen cells. Cell Tissue Kinet 3: 393-403.

Friedenstein AJ, Gorskaja UF, Kulagina NN (1976) Fibroblast precursors in normal and irradiated mouse hematopoietic organs. Exp Hematol 4: 267-274.

Fuchs E, Tumbar T, Guasch G (2004) Socializing with the neighbours: stem cells and their niche. Cell 116: 769778 .

Gindraux F, Selmani Z, Obert L, Davani S, Tiberghien P, Hervé P, Deschaseaux F (2007) Human and rodent bone marrow mesenchymal stem cells that express primitive 
stem cell markers can be directly enriched by using the CD49a molecule. Cell Tissue Res 327: 471-483.

Guo Z, Li H, Li X, Yu X, Wang H, Tang P, Mao N (2006) In vitro characteristics and in vivo immunosuppressive activity of compact bone-derived murine mesenchymal progenitor cells. Stem Cells 24: $992-$ 1000 .

Haynesworth SE, Goshima I, Goldberg VM, Caplan AI (1992) Characterization of cells with osteogenic potential from bone marrow. Bone 13: 81-88.

Hennig T, Lorenz H, Thiel A, Goetzke K, Dickhut A, Geiger F, Richter W (2007) Reduced Chondrogenic Potential of Adipose Tissue Derived Stromal Cells Correlates With an Altered TGFb Receptor and BMP Profile and Is Overcome by BMP-6. J Cell Physiol 211: 682-691.

Hoffmann A, Pelled G, Turgeman G, Eberle P, Zilberman Y, Shinar H, Keinan-Adamsky K, Winkel A, Shahab S, Navon G, Gross G, Gazit D (2006)Neotendon formation induced by manipulation of the Smad8 signalling pathway in mesenchymal stem cells. J Clin Invest 116: 940-952.

Hofstetter CP, Schwarz EJ, Hess D, Widenfalk J, El Manira A, Prockop DJ, Olson L (2002) Marrow stromal cells form guiding strands in the injured spinal cord and promote recovery. Proc Natl Acad Sci USA 99: 2199-2204.

Honczarenko M, Le Y, Swierkowski M, Ghiran I, Glodek AM, Silberstein LE (2006) Human bone marrow stromal cells express a distinct set of biologically functional chemokine receptors. Stem Cells 24: 1030-1041.

Horwitz EM, Prockop DJ, Fitzpatrick LA, Koo WWK, Gordon PL, Neel M, Sussman M, Orchard P, Marx JC, Pyeritz RE, Brenner MK (1999) Transplantability and therapeutic effects of bone marrow-derived mesenchymal cells in children with osteogenesis imperfecta. Nat Med 5: 309-313.

Horwitz EM, Gordon PL, Koo WK, Marx JC, Neel MD, McNall RY, Muul L, Hofmann T (2002) Isolated allogeneic bone marrow-derived mesenchymal cells engraft and stimulate growth in children with osteogenesis imperfecta: implications for cell therapy of bone. Proc Natl Acad Sci USA 99: 8932-8937.

Horwitz EM, Le Blanc K, Dominici M, Mueller I, Slaper-Cortenbach I, Marini FC, Deans RJ, Krause DS, Keating A (2005) Clarification of the nomenclature for MSC: The International Society for Cellular Therapy position statement. Cytotherapy. 7: 393-395.

Hwang JH, Shim SS, Seok OS, Lee HY, Woo SK, Kim BH, Song HR, Lee JK, Park YK (2009) Comparison of cytokine expression in mesenchymal stem cells from human placenta, cord blood, and bone marrow. J Korean Med Sci 24: 547-554.

In 't Anker PS, Scherjon SA, Kleijburg-van der Keur C, Noort WA, Claas FH, Willemze R, Fibbe WE, Kanhai $\mathrm{HH}$ (2003) Amniotic fluid as a novel source of mesenchymal stem cells for therapeutic transplantation. Blood 102: 1548-1549.

Ivanova-Todorova E, Bochevb I, Mourdjeva M, Dimitrov R, Bukarev D, Kyurkchiev S, Tivchev P, Altunkova I, Kyurkchiev DS (2009) Adipose tissue- derived mesenchymal stem cells are more potent suppressors of dendritic cells differentiation compared to bone marrow-derived mesenchymal stem cells. Immunol Lett 126: 37-42.

Jaiswal N, Haynesworth SE, Caplan AI, Bruder SP (1997) Osteogenic differentiation of purified, cultureexpanded human mesenchymal stem cells in vitro. J Cell Biochem 64: 295-312.

Ji JF, He BP, Dheen ST, Tay SS (2004) Interactions of chemokines and chemokine receptors mediate the migration of mesenchymal stem cells to the impaired site in the brain after hypoglossal nerve injury. Stem Cells 22: 415-427.

Jo CH, Ahn HJ, Kim HJ, Seong SC, Lee MC (2007) Surface characterization and chondrogenic differentiation of mesenchymal stromal cells derived from synovium. Cytotherapy 9: 316- 327.

Jones E, McGonagle D (2008) Human bone marrow mesenchymal stem cells in vivo. Rheumatology 47: 126131.

Jones EA, Kinsey SE, English A, Jones RA, Straszynski L, Meredith DM, Markham AF, Jack A, Emery P, McGonagle D (2002) Isolation and characterization of bone marrow multipotential mesenchymal progenitor cells. Arthritis Rheum 46: 3349-3360.

Jones EA, English A, Henshaw K, Kinsey SE, Markham AF, Emery P, McGonagle D (2004) Enumeration and phenotypic characterization of synovial fluid multipotential mesenchymal progenitor cells in inflammatory and degenerative arthritis. Arthritis Rheum 50: 817-827.

Jones EA, English A, Kinsey SE, Straszynski L, Emery P, Ponchel F, McGonagle D (2006) Optimization of a flow cytometry-based protocol for detection and phenotypic characterization of multipotent mesenchymal stromal cells from human bone marrow. Cytometry Part B (Clinical Cytometry) 70B: 391-399.

Karp JM, Leng Teo GS. (2009) Mesenchymal stem cell homing: the devil is in the details. Cell Stem Cell 4: 206-216.

Karystinou A, Dell'Accio F, Kurth TB, Wackerhage H, Khan IM, Archer CW, Jones EA, Mitsiadis TA, De Bari C (2009) Distinct mesenchymal progenitor cell subsets in the adult human synovium. Rheumatology 48: 1057-1064.

Kiel MJ, Morrison SJ (2009) Uncertainty in the niches that maintain haematopoietic stem cells. Nat Rev Immunol 8: 290-301.

Kitaori T, Ito H, Schwarz EM, Tsutsumi R, Yoshitomi H, Oishi S, Nakano M, Fujii N, Nagasawa T, Nakamura T (2009) Stromal cell-derived factor 1/CXCR4 signalling is critical for the recruitment of mesenchymal stem cells to the fracture site during skeletal repair in a mouse model. Arthritis Rheum 60: 813-823.

Kon E, Muraglia A, Corsi A, Bianco P, Marcacci M, Martin I, Boyde A, Ruspantini I, Chistolini P, Rocca M, Giardino R, Cancedda R, Quarto R (2000) Autologous bone marrow stromal cells loaded onto porous hydroxyapatite ceramic accelerate bone repair in criticalsize defects of sheep long bones. J Biomed Mater Res 49: 328-337. 
Kraitchman DL, Tatsumi M, Gilson WD, Ishimori T, Kedziorek D, Walczak P, Segars WP, Chen HH, Fritzges D, Izbudak I, Young RG, Marcelino M, Pittenger MF, Solaiyappan M, Boston RC, Tsui BM, Wahl RL, Bulte JW (2005). Dynamic imaging of allogeneic mesenchymal stem cells trafficking to myocardial infarction. Circulation 112: 1451-1461.

Kuhn NZ, Tuan RS (2010) Regulation of stemness and stem cell niche of mesenchymal stem cells: implications in tumorigenesis and metastasis. J Cell Physiol 222: 268277.

Lasala GP, Silva JA, Gardner PA, Minguell JJ (2010) Combination stem cell therapy for the treatment of severe limb ischemia: Safety and efficacy analysis. Angiology, in press.

Luria EA, Owen ME, Friedenstein AJ, Morris JF, Kuznetsov SA (1987) Bone formation in organ cultures of bone marrow. Cell Tissue Res 248: 449-454.

Ma J, Ge J, Zhang S, Sun A, Shen J, Chen L, Wang K, Zou Y (2005) Time course of myocardial stromal cellderived factor 1 expression and beneficial effects of intravenously administered bone marrow stem cells in rats with experimental myocardial infarction. Basic Res Cardiol 100: 217-223.

Mahmud N, Pang W, Cobbs C, Alur P, Borneman J, Dodds R, Archambault M, Devine S, Turian J, Bartholomew A, Vanguri P, Mackay A, Young R, Hoffman $\mathrm{R}$ (2004) Studies of the route of administration and role of conditioning with radiation on unrelated allogenic mismatched mesenchymal stem cell engraftment in a nonhuman primate model. Exp Hematol 32: 494-501.

Maloney MA, Lamela RA, Patt HM (1985) The question of bone marrow stromal fibroblast traffic. Ann N Y Acad Sci 459: 190-197.

Mansilla E, Mar1'n GH, Drago H, Sturla F, Salas E, Gardiner C, Bossi S, Lamonega R, Guzmán A, Nuñez A, Gil MA, Piccinelli G, Ibar R, Soratti C (2006) Bloodstream cells phenotypically identical to human mesenchymal bone marrow stem cells circulate in large amounts under the influence of acute large skin damage: New evidence for their use in regenerative medicine. Transpl Proc 38: 967 969.

Marinova-Mutafchieva L, Taylor P, Funa K, Maini RN, Zvaifler NJ (2000) Mesenchymal cells expressing bone morphogenetic protein receptors are present in the rheumatoid arthritis joint. Arthritis Rheum 43: 2046-2055.

Meijer GJ, de Bruijn JD, Koole R, van Blitterswijk CA (2008) Cell based bone tissue engineering in jaw defects. Biomaterials 29: 3053-3061.

Miao Z, Jin J, Chen L, Zhu J, Huang W, Zhao J, Qian H, Zhang X (2006) Isolation of mesenchymal stem cells from human placenta: Comparison with human bone marrow mesenchymal stem cells. Cell Biol Int 30: 681687.

Mitsiadis TA, Barrandon O, Rochat A, Barrandon Y, De Bari C (2007) Stem cell niches in mammals. Exp Cell Res 313: 3377-3385.

Morigi M, Imberti B, Zoja C, Corna D, Tomasoni S, Abbate M, Rottoli D, Angioletti S, Benigni A, Perico N, Alison M, Remuzzi G (2004) Mesenchymal stem cells are renotropic, helping to repair the kidney and improve function in acute renal failure. J Am Soc Nephrol 15: 1794 1804.

Morikawa S, Mabuchi Y, Kubota Y, Nagai Y, Niibe K, Hiratsu E, Suzuki S, Miyauchi-Hara C, Nagoshi N, Sunabori T, Shimmura S, Miyawaki A, Nakagawa T, Suda T, Okano H, Matsuzaki Y (2009) Prospective identification, isolation, and systemic transplantation of multipotent mesenchymal stem cells in murine bone marrow. J Exp Med 206: 2483-2496.

Munoz-Elias G, Marcus AJ, Coyne TM, Woodbury D, Black IB (2004) Adult bone marrow stromal cells in the embryonic brain: engraftment, migration, differentiation, and long-term survival. J Neurosci 24: 4585-4595.

Muraglia A, Martin I, Cancedda R, Quarto R (1998) A nude mouse model for human bone formation in unloaded conditions. Bone 22: 131S.

Muraglia A, Cancedda R, Quarto R (2000) Clonal mesenchymal progenitors from human bone marrow differentiate in vitro according to a hierarchical model. J Cell Sci 113: 1161-1166.

Nakahara H, Dennis JE, Bruder SP, Haynesworth SE, Lennon DP, Caplan AI (1991) In vitro differentiation of bone and hypertrophic cartilage from periosteal-derived cells. Exp Cell Res 195: 492-503.

Ohgushi H, Okumura M (1990) Osteogenic capacity of rat and human marrow cells in porous ceramics. Acta Orthop Scand 61: 431-434.

Ohtaki H, Ylostalo JH, Foraker JE, Robinson AP, Reger RL, Shioda S, Prockop DJ (2008) Stem/progenitor cells from bone marrow decrease neuronal death in global ischemia by modulation of inflammatory/immune responses. Proc Natl Acad Sci USA 105: 14638-14643.

Peister A, Mellad JA, Larson BL, Hall BM, Gibson LF, Prockop DJ (2004) Adult stem cells from bone marrow (MSCs) isolated from different strains of inbred mice vary in surface epitopes, rates of proliferation, and differentiation potential. Blood 103: 1662-1668.

Peled A, Petit I, Kollet O, Magid M, Ponomaryov T, Byk T, Nagler A, Ben-Hur H, Many A, Shultz L, Lider O, Alon R, Zipori D, Lapidot T (1999) Dependence of human stem cell engraftment and repopulation of NOD/SCID mice on CXCR4. Science 283: 845-848.

Pelttari K, Winter A, Steck E, Goetzke K, Hennig T, Ochs BG, Aigner T, Richter W (2006) Premature induction of hypertrophy during in vitro chondrogenesis of human mesenchymal stem cells correlates with calcification and vascular invasion after ectopic transplantation in SCID mice. Arthritis Rheum 54: 3254-3266.

Phinney DG, Prockop DJ (2007) Concise review: Mesenchymal stem/multi-potent stromal cells (MSCs): The state of transdifferentiation and modes of tissue repair Current views. Stem Cells 25: 2896-2902.

Pittenger MF, Mackay AM, Beck SC, Jaiswal RK, Douglas R, Mosca JD, Moorman MA, Simonetti DW, Craig S, Marshak DR (1999) Multilineage potential of adult human mesenchymal stem cells. Science 284: 143147.

Prockop DJ (1997) Marrow stromal cells as stem cells for nonhematopoietic tissues. Science 276: 71-74. 
Qiu YS, Shahgaldi BF, Revell WJ, Heatley FW (2003) Observations of subchondral plate advancement during osteochondral repair: a histomorphometric and mechanical study in the rabbit femoral condyle. Osteoarthritis Cartilage 11: $810-820$.

Quarto R, Mastrogiacomo M, Cancedda R, Kutepov SM, Mukhachev V, Lavroukov A, Kon E, Marcacci M (2001) Repair of large bone defects with the use of autologous bone marrow stromal cells. N Engl J Med 344: 385-386.

Quirici N, Soligo D, Bossolasco P, Servida F, Lumini C, Lambertenghi Deliliers G (2002) Isolation of bone marrow mesenchymal stem cells by anti-nerve growth factor receptor antibodies. Exp Hematol 30: 783-791.

Reya T, Duncan AW, Ailles L, Domen J, Scherer DC, Willert K, Hintz L, Nusse R, Weissman IL (2003) A role for Wnt signalling in self-renewal of haematopoietic stem cells. Nature 423: 409-414.

Rombouts WJ, Ploemacher RE (2003) Primary murine MSC show highly efficient homing to the bone marrow but lose homing ability following culture. Leukemia 17: 160-170.

Roubelakis MG, Pappa KI, Bitsika V, Zagoura D, Vlahou A, Papadaki HA, Antsaklis A, Anagnou NP (2007) Molecular and proteomic characterization of human mesenchymal stem cells derived from amniotic fluid: Comparison to bone marrow mesenchymal stem cells. Stem Cells Dev 16: 931-951.

Sackstein R, Merzaban JS, Cain DW, Dagia NM, Spencer JA, Lin CP, Wohlgemuth R (2008) Ex vivo glycan engineering of CD44 programs human multipotent mesenchymal stromal cell trafficking to bone. Nat. Med 14: 181-187.

Sarugaser R, Lickorish D, Baksh D, Hosseini MM, Davies JE (2005) Human umbilical cord perivascular (HUCPV) cells: A source of mesenchymal progenitors. Stem Cells 23: 220-229.

Sasaki M, Abe R, Fujita Y, Ando S, Inokuma D, Shimizu H (2008) Mesenchymal stem cells are recruited into wounded skin and contribute to wound repair by transdifferentiation into multiple skin cell type. J Immunol 180: 2581-2587.

Schenk S, Mal N, Finan A, Zhang M, Kiedrowski M, Popovic Z, McCarthy PM, Penn MS (2007) Monocyte chemotactic protein-3 is a myocardial mesenchymal stem cell homing factor. Stem Cells 25: 245-251.

Semerad CL, Christopher MJ, Liu F, Short B, Simmons PJ, Winkler I, Levesque JP, Chappel J, Ross FP, Link DC (2005) G-CSF potently inhibits osteoblast activity and CXCL12 mRNA expression in the bone marrow. Blood. 106: 3020-3027.

Sensebé L (2008) Clinical grade production of mesenchymal stem cells. Bio-Med Mat Eng 18: S3-S10.

Sensebé L, Krampera M, Schrezenmeier H, Bourin P, Giordano R (2010) Mesenchymal stem cells for clinical application. Vox Sanguinis 98: 93-107.

Sordi V, Malosio ML, Marchesi F, Mercalli A, Melzi R, Giordano T, Belmonte N, Ferrari G, Leone BE, Bertuzzi F, Zerbini G, Allavena P, Bonifacio E, Piemonti L (2005) Bone marrow mesenchymal stem cells express a restricted set of functionally active chemokine receptors capable of promoting migration to pancreatic islets. Blood 106: 419427.

Sugiyama T, Kohara H, Noda M, Nagasawa T (2006) Maintenance of the hematopoietic stem cell pool by CXCL12-CXCR4 chemokine signalling in bone marrow stromal cell niches. Immunity 25: 977-988.

Sung JH, Yang HM, Park JB, Choi GS, Joh JW, Kwon CH, Chun JM, Lee SK, Kim SJ (2008) Isolation and characterization of mouse mesenchymal stem cells. Transpl Proc 40: 2649-2654.

Takashima Y, Era T, Nakao K, Kondo S, Kasuga M, Smith AG, Nishikawa SI (2007) Neuroepithelial cells supply an initial transient wave of MSC differentiation. Cell 129:1377-1388.

Tonti GA, Mannello F (2008) From bone marrow to therapeutic applications: different behaviour and genetic/ epigenetic stability during mesenchymal stem cell expansion in autologous and foetal bovine sera? Int J Dev Biol 52: 1023-1032.

Wakitani S, Saito T, Caplan AI (1995) Myogenic cells derived from rat bone marrow mesenchymal stem cells exposed to 5-azacytidine. Muscle Nerve 18: 1417-1426.

Wilson A, Trumpp A (2006) Bone-marrow haematopoietic-stem-cell niches. Nat Rev Immunol 6: 93106.

Woodbury D, Schwarz EJ, Prockop DJ, Black IB (2000) Adult rat and human bone marrow stromal cells differentiate into neurons. J Neurosci Res 61: 364-370.

Wynn RF, Hart CA, Corradi-Perini C, O’Neill L, Evans CA, Wraith JE, Fairbairn LJ, Bellantuono I (2004) A small proportion of mesenchymal stem cells strongly expresses functionally active CXCR4 receptor capable of promoting migration to bone marrow. Blood 104: 2643-2645.

$\mathrm{Xu}$ J, Woods CR, Mora AL, Joodi R, Brigham KL, Iyer S, Rojas M (2007) Prevention of endotoxin-induced systemic response by bone marrow-derived mesenchymal stem cells in mice. Am J Physiol Lung Cell Mol Physiol 293: L131-141.

Yoo KH, Jang IK, Lee MW, Kim HE, Yang MS, Eom Y, Lee JE, Kim YJ, Yang SK, Jung HJ, Sung KW, Kim CW, Koo HH (2009) Comparison of immunomodulatory properties of mesenchymal stem cells derived from adult human tissues. Cellular Immunol 259: 150-156.

Zappia E, Casazza S, Pedemonte E, Benvenuto F, Bonanni I, Gerdoni E, Giunti D, Ceravolo A, Cazzanti F, Frassoni F, Mancardi G, Uccelli A (2005) Mesenchymal stem cells ameliorate experimental autoimmune encephalomyelitis inducing T-cell anergy. Blood 106: 1755-1761.

Zhu Y, Liu T, Song K, Fan X, Ma X, Cui Z (2008) Adipose-derived stem cell: a better stem cell than BMSC. Cell Biochem Funct 26: 664-675.

Zuk PA, Zhu M, Ashjian P, De Ugarte DA, Huang JI, Mizuno H, Alfonso ZC, Fraser JK, Benhaim P, Hedrick MH (2002) Human adipose tissue is a source of multipotent stem cells. Mol Biol Cell 13: 4279-4295.

Zvaifler NJ, Marinova-Mutafchieva L, Adams G, Edwards CJ, Moss J, Burger JA, Maini RN (2000) Mesenchymal precursor cells in the blood of normal individuals. Arthritis Res 2: 477-488. 


\section{Discussion with Reviewers}

Reviewer I: What are the quantified data indicating that MSCs home?

Authors: Several studies, cited throughout our review article, have reported quantification of MSC homing and engraftment in multiple tissues and organs. Chemotactic mechanisms of MSC homing remain largely unknown and the engraftment of MSCs in organs and tissues may be simply stochastic or due to multiple factors including increased blood supply secondary to injury. Hereafter, we briefly report a few selected studies on quantitation of homing and engraftment of MSCs. Results cannot be compared due to differences in experimental systems and detection methods.

Horwitz et al. (1999) (text reference) showed engraftment of mesenchymal cells in two children with Osteogenesis Imperfecta (OI) following transplantation of bone marrow (BM) from HLA-identical or single-antigenmismatched siblings after ablative conditioning therapy. To assess for the engraftment of donor-derived cells in the recipient, osteoblasts were cultured from fresh bone biopsy specimens. In one patient the donor cells were quantified at a frequency of $1.5 \%$ by in situ hybridization for $\mathrm{Y}$ chromosome, while in the other patient the frequency was $2 \%$ as determined by DNA polymorphism analysis.

Horwitz et al. (2002) (text reference) showed that in five out of six OI patients there were signs of engraftment of retrovirally-infected cultured MSCs. Donor cells were detected by PCR for a retroviral marker. Engraftment in BM stroma and bone of donor cells did not exceed $1 \%$. Despite such low engraftment, clinical improvement ranged from $60 \%$ to $94 \%$ compared with $0 \%$ to $40 \%$ over the 6 months immediately preceding the infusions (Horwitz et al., 2002).

In baboons, Devine et al. (2001) (text reference) detected by PCR in the BM of recipients retrovirally transduced BM-derived syngeneic or allogeneic MSCs for over 1 year after their co-infusion with autologous HSCs. The Authors also identified donor MSC-derived cells by flow cytometry in the BM aspirate from one experimental animal at day 33 post-infusion, in a percentage of $1 \%$.

De Bari et al. (2003) (text reference) quantified by RTPCR using species-specific primers the numbers of "human cell equivalents" engrafting in nude mouse skeletal muscles after intramuscular injection of human synovial membranederived MSCs. They also performed an intravenous administration of $5 \times 10^{6}$ human MSCs into nude mice. MSCs homed preferentially to the injured (cardiotoxintreated) tibialis anterior muscle as opposed to the contralateral uninjured control muscle. At 3 weeks, about $2 \times 10^{3}$ human cells were detected in the injured muscles, while they were undetectable in the uninjured control muscles.

Rombouts and Ploemacher (2003) (text reference) performed experiments of intravenous infusion of uncultured (obtained from CD45-/low BM cells) or cultured BM-MSCs in irradiated and control syngeneic mice. The Authors, analyzing the ratio of donor vs. host CFU-f from the organs of transplanted mice, assessed in a quantitative manner the homing, in vivo expansion and tissue distribution of donor-derived MSCs in BM, spleen, thymus and lymph nodes.

Belema-Bedada et al. (2008) (text reference) showed that in mice overexpressing MCP-1 in the heart, intravenously infused allogeneic eGFP+ BM-MSCs migrated preferentially toward the MCP-1 overexpressing heart as compared with wild-type animals, in which migration toward heart was negligible. Quantitation was performed by counting eGFP+ cells on histological sections and by real-time RT-PCR for eGFP on whole hearts. In mice operated to induce cardiac ischemiareperfusion, there was a requirement for an intact CCR2/ FRONT signalling in the donor MSCs to migrate toward the site of injury.

Sackstein et al. (2008) (text reference) injected human MSCs expressing a variant of CD44, HCELL, which permits selective MSC migration toward bone. While human MSCs that did not express HCELL were not retrieved in the BM of recipient mice, the HCELL+ cells migrated to the murine bone marrow at an endosteal location. Cells positive for human CD44 and for human osteocalcin were quantified by microscopic analysis.

Morikawa et al. (2009) (text reference) studied migration of murine uncultured $\mathrm{EGFP}+\mathrm{Sca} 1+\mathrm{PDGFR} \alpha+$ CD45.1-Ter119- MSCs in EGFP-CD45.1- mice when cotransplanted with HSCs from EGFP-CD45.1+ mice. The $\mathrm{EGFP}+\mathrm{CD} 45.1-\mathrm{MSC}$ were found in the recipient BM up to 16 weeks after transplantation. By contrast, cultured MSCs were not found to migrate into the recipient BM. Flow cytometry was carried out to detect and quantify donor EGFP+ MSCs homed into the host BM. The Authors also cultured the host BM as single cells and were able to produce EGFP+ fibroblastic clones, demonstrating effective engraftment of MSCs in the host BM.

Reviewer II: How do the results of Patt and Maloney using mouse symbionts compare to more recent results on MSC homing?

Authors: Maloney et al. (1985) (text reference) demonstrated that in mice in parabiotic equilibrium where one partner had been X-irradiated, repopulation of the CFU-F compartments of the BM in the irradiated mouse resulted from recovery of the local CFU-F and not from migration of CFU-Fs from the parabiotic, non-irradiated partner. Later studies, using different models and detection systems, have demonstrated engraftment of donor MSCs in the recipient BM (see above). Resident BM-MSCs are known to be resistant to lethal irradiation and, due to their quiescence and permanence in G0, they can survive despite their inability to replicate, thus competing for the niche with the donor MSCs (Morikawa et al., 2009). Independent of the model system, the frequency of MSC engraftment is low and difficult to detect, also in view of the lack of MSC specific markers. It is therefore anticipated that the combination of mouse genetics and sophisticated novel detection systems will allow a more detailed analysis of MSC homing and engraftment in vivo, as for instance in the study by Morikawa. (Editor's note: All references cited in the Discussion with Reviewers are text references). 